\title{
Nursing assistance in patient care with external ventricular drain: a scoping review
}

\author{
Cuidados de enfermagem na assistência ao paciente com derivação ventricular externa: scoping review \\ Atención de enfermería en cuidado al paciente con derivación ventricular externa: scoping review
}

Victoria Tiyoko Moraes Sakamoto'
ORCID: 0000-0002-4646-6848
Tainara Wink Vieira'
ORCID: 0000-0003-1404-1009
Karin Viegas'
ORCID: 0000-0002-2546-9281
Carine Raquel Blatt'
ORCID: 0000-0001-5935-1196
Rita Catalina Aquino Caregnato'
ORCID: 0000-0001-7929-7676

'Universidade Federal de Ciências da Saúde de Porto Alegre. Porto Alegre, Rio Grande do Sul, Brazil.

How to cite this article: Sakamoto VTM, Vieira TW, Viegas K, Blatt CR, Caregnato RCA. Nursing assistance in patient care with external ventricular drain: a scoping review.

Rev Bras Enferm. 2021;74(2):e20190796. doi: http://dx.doi.org/10.1590/0034-7167-2019-0796

\section{Corresponding author:}

Victoria Tiyoko Moraes Sakamoto

E-mail: vic.sakamoto@gmail.com

EDITOR IN CHIEF: Antonio José de Almeida Filho ASSOCIATE EDITOR: Ana Fátima Fernandes

Submission: 11-10-2019

Approval: 05-21-2020

\begin{abstract}
Objectives: to map the available evidence about nursing care aimed at adult patients using external ventricular drain. Methods: this is a review using the scoping review method. Results: Initially, 965 studies were identified and, after the eligibility criteria, a sample of 54 publications was obtained. Each of them was assessed according to GRADE, resulting in three studies with high quality; 14 with moderate quality; 32 with low quality; and five with very low quality. It was highlighted 20 nursing care subdivided into nine categories, namely: drainage system; bed positioning and mobilization; catheter care; monitoring of intracranial pressure; and medication administration. Conclusions: the scoping review made it possible to identify the main nursing care directed to adult patients undergoing placement of external ventricular drain from the evidence available to date.

Descriptors: Evidence-Based Nursing; Patient Care; Nursing Care; Patient Care Planning; Review.
\end{abstract}

\section{RESUMO}

Objetivos: mapear as evidências disponíveis acerca dos cuidados de enfermagem direcionados ao paciente adulto em uso de derivação ventricular externa. Métodos: trata-se de uma revisão utilizando o método scoping review. Resultados: inicialmente, identificaram-se 965 estudos e, após os critérios de elegibilidade, obteve-se amostra de 54 publicações. Cada um deles foi avaliado de acordo com o GRADE, resultando em três estudos com qualidade alta; 14 com qualidade moderada; 32 com qualidade baixa; e cinco com qualidade muito baixa. Destacaram-se 20 cuidados de enfermagem, subdivididos em nove categorias como: sistema de drenagem; posicionamento e mobilização no leito; cuidados com o cateter; monitorização da pressão intracraniana; e administração de medicamentos. Conclusões: a realização do scoping review permitiu identificar os principais cuidados de enfermagem direcionados ao paciente adulto submetido à colocação de derivação ventricular externa a partir das evidências disponíveis até o momento.

Descritores: Enfermagem Baseada em Evidências; Assistência ao Paciente; Cuidados de Enfermagem; Planejamento de Assistência ao Paciente; Revisão.

\section{RESUMEN}

Objetivos: mapear la evidencia disponible sobre la atención de enfermería dirigida a pacientes adultos que usan derivación ventricular externa. Métodos: esta es una revisión que utiliza el método de scoping review. Resultados: inicialmente, se identificaron 965 estudios y, después de los criterios de elegibilidad, se obtuvo una muestra de 54 publicaciones. Cada uno de ellos fue evaluado según GRADE, lo que resultó en tres estudios con alta calidad; 14 con calidad moderada; 32 con baja calidad; y nueve con muy baja calidad. Hubo 20 cuidados de enfermería, divididos en nueve categorías, tales como: sistema de drenaje; posicionamiento y movilización de la cama; cuidado del catéter; monitorización de la presión intracraneal; y administración de medicamentos. Conclusiones: la revisión del alcance permitió la identificación de los principales cuidados de enfermería dirigidos a pacientes adultos sometidos a la colocación de un bypass ventricular externo con base en la evidencia disponible hasta el momento. Descriptores: Enfermería Basada en la Evidencia; Atención al Paciente; Atención de Enfermería; Planificación de Atención al Paciente; Revisión. 


\section{INTRODUCTION}

External ventricular drain (EVD) is a health technology and is a diagnostic and therapeutic tool(1). It is considered the gold standard when used in the treatment of patients with neurological pathologies, where intracranial hypertension $(\mathrm{ICH})$ occurs in cases such as hydrocephalus, hemorrhage, tumor, meningitis or brain injury resulting from traumatic brain injury $(\mathrm{TBI})^{(2-3)}$.

EVD allows continuous monitoring and assists in reducing intracranial pressure (ICP), allowing drainage of cerebrospinal fluid (CSF) or blood as well as administration of medications or collection of CSF, if necessary ${ }^{(4)}$. This technology is contraindicated in patients with a coagulation disorder or anticoagulated by drug therapy, or with an infection in the scalp or abscesses in the area, due to the high risk of infection of the central nervous system such as meningitis and ventriculitis(5).

Some complications can occur and affect patients using EVD. Among them are infection (identified from signs such as hyperthermia, hyperemia or drainage of exudate/secretion); system obstruction (perceived when CSF drainage is below the minimum limit or the CSF wave is flat on the monitor); excess CSF drainage. EVD can cause bleeding or ventricular complications or even accidental catheter removal, requiring neurosurgical intervention ${ }^{(6)}$.

Considering the number of variations in care techniques associated with care to patients undergoing EVD, it is important to associate nursing interventions that help to maintain an adequate therapeutic environment ${ }^{(7)}$. The multidisciplinary staff, especially the nursing staff, is essential for care to patients, most of whom are hospitalized in Intensive Care Units (ICU). Therefore, seeking qualification of care practices must be constant, aiming to decrease the rates of nosocomial infection and, consequently, mortality rates or length of stay in intensive care beds.

Currently, the use of scientific evidence is essential for decisionmaking, ensuring patient safety. Evidence-based practice aims to contribute to the solution of daily praxis problems, based on the choice of the best scientific evidence available for care ${ }^{(8-9)}$. It is characterized as the simultaneous use of theoretical knowledge applying in practice the best clinical evidence available, helping in clinical decision-making, considering the values of patients ${ }^{(10)}$.

Thus, seeking qualification of nursing care practices should be a constant, aiming to decrease infection rates related to health care and, consequently, decrease patient mortality and length of hospital stay. It is intended that this review helps the nursing staff to promote safe, quality and excellent care for adult patients with EVD.

\section{OBJECTIVES}

To map the available evidence about nursing care directed at adult patients using EVD.

\section{METHODS}

\section{Ethical aspects}

All ethical and scientific requirements for carrying out the research were respected. It was based on legal provisions, ensuring methodological rigor in the treatment and presentation of data, with fidelity to the information contained in the original documents that supported the results.

\section{Study design}

This is a scoping review, following the recommendations of the Joanna Briggs Institute (JBI) ${ }^{(11)}$, based on the theoretical framework proposed by Arksey and O'Malley ${ }^{(12)}$ and improved by Levac, Colquhoun and O'Brien ${ }^{(13)}$.

The value of this method for evidence-based practice lies in the broad analysis of an area in order to identify gaps in knowledge, clarify key concepts and report the types of evidence that guide field practices ${ }^{(11-15)}$. The structure of this type of review follows the following steps, namely: a) definition of the research objective and question; b) development of inclusion criteria; c) description of the planned approach to the research, from selection, extraction and creation of evidence; d) search for evidence; e) selection of evidence; $f$ ) extraction of evidence; $g$ ) delimitation of the key information of the evidence; $h$ ) synthesis of information in line with the objective and research question; and i) consultation with experts ${ }^{(11)}$ (the last one is optional).

PRISMA-SCR checklist, registered with EQUATOR, was used to conduct and review the study, seeking to improve research quality and transparency ${ }^{(16)}$.

In the first stage, the research question for investigation was structured based on the acronym PCC ( $\mathrm{P}$ - Population: adult patients undergoing placement of EVD; C - Concept: nursing care; C - Context: ICU). It was elaborated as follows: "what are the main nursing care directed to the adult patient submitted to the placement of assisted EVD in ICU?"

\section{Inclusion and exclusion criteria}

The second stage consisted of delimiting the criteria, in congruence between the objective and the research question. Studies involving adult patients submitted to EVD placement were included. Nursing care was approached with interventions aimed at this profile of patients assisted in the ICU. Studies were also used with outcomes related to care to patients with EVD, system length of stay, possible EVD-related complications, infections and mortality.

Studies with patients of other age groups or who addressed other therapeutic managements, such as decompressive craniotomy, catheter for monitoring or conservative treatment were excluded. Opinion-based, editorial or letter to the editor studies were not included in the review. We chose to select complete studies that were available in full and that were useful to answer the research question. Searches in Portuguese, English and Spanish were determined. There was no delimitation of the year of publication.

\section{Study protocol}

The following steps (extraction, creation and search for evidence) correspond to the research strategy and were reported comprehensively in accordance with JBI recommendations. PubMED, Cochrane, CINAHL, Scopus, Virtual Health Library, Google Scholar, references present in the "gray literature" available at 
greylit.org have been consulted. This website provides a list of recognized sources for this type of search and reference lists of selected relevant studies. JBI recommends that all reference lists of selected studies be searched in order to identify any potential additional study not mapped to the strategy used ${ }^{(11)}$.

An initial survey was carried out between February and July 2017 , with the aim of identifying relevant words contained in the title and summary of studies, as well as the index terms used to describe the study. To search for articles, controlled descriptors existing at DeCS, MeSH and CINAHL were crossed, together with uncontrolled descriptors related to EVD. Boolean operators AND and OR were used, as described in the search strategy: (vascular access devices OR cerebral fluid pressure OR intracranial pressure OR drainage OR cerebrospinal fluid OR cerebrospinal fluid lake OR cerebrovascular disorders external ventriculostomy OR external ventricular catheters OR external ventricular catheter OR external ventricular derivation OR external ventricular drainage catheters OR external ventricular drainage catheter OR external ventricular drainage systems OR external ventricular drainage system OR external ventricular drainage evd OR external ventricular drains OR external ventricular drainage OR external ventricular drain evd OR external ventricular drain OR external ventricular) AND (critical care OR intensive care units OR patient care management OR nursing care OR nursing OR patient care planning OR primary nursing OR nursing process OR critical care nursing) AND (infection OR death OR intracranial hypertension OR intracranial hemorrhages OR ventricular collapse OR length of stay).

To select the studies, data collection was performed by two researchers, strictly following the same process of applying the eligibility and analysis criteria, in a paired and independent way. As a result, selection from reading the titles, abstracts and reading content in full was carried out by both and, in case of divergence, an agreement was adopted. In the following seven months, a search was made on the different information resources, allocating one month for each database. By the end of the survey in June 2018, a brief survey was repeated in order to identify whether any new publications were included that fit the criteria developed by the researchers. The evidence selection step took place in the following order: exclusion of duplicate studies; reading the titles; reading of abstracts; reading the entire text applying the eligibility criteria.

\section{Analysis of results}

The final stages of extracting and delimiting the key information from he evidence were carried out based on numerical descriptive analysis to characterize the studies. There was further categorization of the evidence selected for thematic analysis, in order to align and summarize the information with the objective and the research question. Moreover, each of the studies was assessed according to the degree of quality of the evidence, based on GRADE (Grading of Recommendations, Assessment, Development and Evaluation) Working Group guidelines ${ }^{(17)}$. As recommended in this method, a summary table was created containing the results, using the weighting system that decreases or increases the quality of the evidence according to the design of each study. The factors that decrease quality correspond to the limitations of the study such as risk of bias, heterogeneity, indirect evidence, imprecision, and publication bias. Those that increase quality (which may be applicable to observational studies) are the large magnitude of the effect, the dose-response gradient and the biases that would reduce the effect found.

\section{RESULTS}

Through search, 965 articles have been identified and, after screening and applying the eligibility criteria, a sample of 54 selected articles was obtained. The following diagram illustrates the study search strategy (Figure 1).

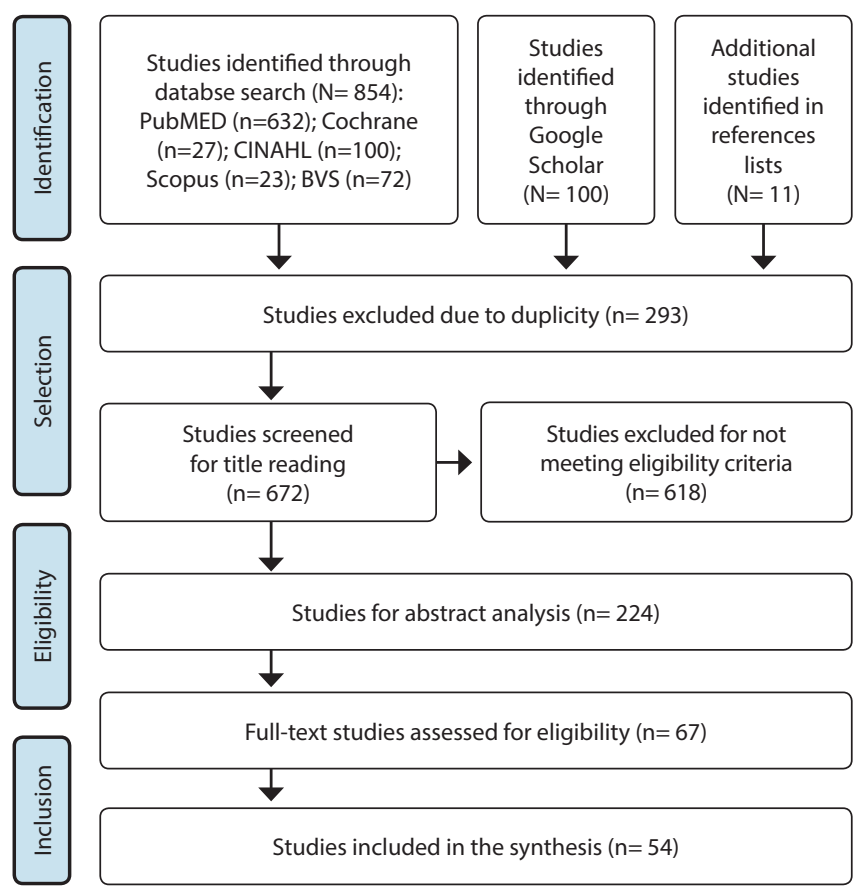

Note: PubMED - National Library of Medicine; CINAHL - Cumulative Index to Nursing and Allied Health Literature; BVS - Virtual Health Library.

Figure 1 - Diagram adapted from the strategy to search for articles on nursing care of adult patients with external ventricular drain

Chart 1 presented the title, year, outline of the articles selected in this review with their respective assessments of quality and degree of evidence, according to GRADE recommendations ${ }^{(17)}$.

Each of the studies was assessed according to GRADE, resulting in three studies with high quality, 14 with moderate quality, 32 with low quality and five with very low quality. Distributing publications by continents, it was possible to notice that most publications were concentrated in North America $(n=25)$ and Europe $(n=21)$, while Asia $(n=4)$, South America $(n=2)$, Africa $(n=1)$ and Oceania $(n=1)$ contributed with an insignificant number. Regarding the country of origin of each study, 22 are from the United States, 4 from the United Kingdom, 4 from Germany, 3 from Canada, 3 from China, 2 from Austria, 2 from Brazil, 2 from France, 2 from Netherlands, 2 from Sweden, 1 from Australia, 1 from Italy, 1 from Egypt, 1 from Greece and 1 from Singapore. It is also noteworthy that only two studies were published before the 2000s, a Chinese study in 1988, which addressed the risks and complications associated with EVD clamping in intra-hospital transport, and another German one from 1992, when they assessed the risk factors of EVD. 
Chart 1 - Synoptic table with the synthesis of the studies selected in the research

\begin{tabular}{|c|c|c|c|}
\hline Title & $\begin{array}{l}\text { Year } \\
\text { Country }\end{array}$ & Outlining & GRADE \\
\hline Prolonged therapeutic external ventricular drainage: A prospective study & $\begin{array}{r}1988 \\
\text { China } \\
\end{array}$ & Cohort study & Low \\
\hline $\begin{array}{l}\text { Continuous-pressure controlled, external ventricular drainage for treatment of acute } \\
\text { hydrocephalus-evaluation of risk factors: clinical study }\end{array}$ & $\begin{array}{l}1992 \\
\text { Germany }\end{array}$ & Experience report & Low \\
\hline Extraventricular drains: sterile versus aseptic technique & $\begin{array}{c}2002 \\
\text { Australia }\end{array}$ & Cohort study & Low \\
\hline Benchmarking best practice for external ventricular drainage & $\begin{array}{c}2002 \\
\text { United kingdom }\end{array}$ & $\begin{array}{l}\text { Qualitative systematic } \\
\text { review }\end{array}$ & Moderate \\
\hline $\begin{array}{l}\text { Early diagnosis of external ventricular drainage infection: results of a prospective } \\
\text { study }\end{array}$ & $\begin{array}{c}2003 \\
\text { Austria }\end{array}$ & Cohort study & Low \\
\hline $\begin{array}{l}\text { Efficacy of antimicrobial-impregnated external ventricular drain catheters: a } \\
\text { prospective, randomized, controlled trial }\end{array}$ & $\begin{array}{l}2003 \\
\text { USA }\end{array}$ & $\begin{array}{l}\text { Randomized clinical } \\
\text { trial }\end{array}$ & High \\
\hline Risk of infection with prolonged ventricular catheterization & $\begin{array}{l}2004 \\
\text { USA }\end{array}$ & Cohort study & Low \\
\hline $\begin{array}{l}\text { Prevention of external ventricular } \\
\text { drain-related ventriculitis }\end{array}$ & $\begin{array}{l}2005 \\
\text { France }\end{array}$ & Cohort study & Low \\
\hline $\begin{array}{l}\text { External ventricular drain infection: The effect of a strict protocol on infection rates } \\
\text { and a review of the literature }\end{array}$ & $\begin{array}{l}2006 \\
\text { United kingdom }\end{array}$ & Cohort study & Low \\
\hline Nosocomial ventriculitis and meningitis in neurocritical care patients & $\begin{array}{c}2008 \\
\text { Austria }\end{array}$ & Integrative review & Low \\
\hline Risk factors for infections related to external ventricular drainage & $\begin{array}{c}2008 \\
\text { Netherlands }\end{array}$ & Cohort study & Low \\
\hline Paciente neurocrítico. Cuidados de enfermería & $\begin{array}{l}2009 \\
\text { Spain }\end{array}$ & $\begin{array}{l}\text { Quasi-experimental } \\
\text { study }\end{array}$ & Low \\
\hline External ventricular drains in patients & $\begin{array}{c}2009 \\
\text { Canada }\end{array}$ & Cohort study & Low \\
\hline External ventricular drains and mortality in patients with severe traumatic brain injury & $\begin{array}{c}2010 \\
\text { Canada }\end{array}$ & Cohort study & Moderate \\
\hline $\begin{array}{l}\text { Reducing the incidence of intraventricular catheter-related ventriculitis in the } \\
\text { neurology-neurosurgical intensive care unit at a tertiary care center in St Louis, } \\
\text { Missouri: An 8-year follow-up study }\end{array}$ & $\begin{array}{l}2010 \\
\text { USA }\end{array}$ & $\begin{array}{l}\text { Quasi-experimental } \\
\text { study }\end{array}$ & Low \\
\hline $\begin{array}{l}\text { A bundle approach to reduce the incidence of external ventricular and lumbar drain- } \\
\text { related infections }\end{array}$ & $\begin{array}{l}2010 \\
\text { Netherlands }\end{array}$ & Cross-sectional study & Low \\
\hline $\begin{array}{l}\text { External ventricular and lumbar drainage-associated meningoventriculitis: } \\
\text { prospective analysis of time-dependent infection rates and risk factor analysis }\end{array}$ & $\begin{array}{c}2010 \\
\text { Germany }\end{array}$ & Cohort study & Low \\
\hline $\begin{array}{l}\text { Care of the patient undergoing intracranial pressure monitoring/external ventricular } \\
\text { drainage or lumbar drainage }\end{array}$ & $\begin{array}{l}2011 \\
\text { USA }\end{array}$ & $\begin{array}{l}\text { Clinical practice } \\
\text { guideline }\end{array}$ & Moderate \\
\hline $\begin{array}{l}\text { Reduction in external ventricular drain infection rate. Impact of a minimal handling } \\
\text { protocol and antibiotic-impregnated catheters }\end{array}$ & $\begin{array}{l}2011 \\
\text { Spain }\end{array}$ & Case study & Low \\
\hline $\begin{array}{l}\text { Cerebrospinal fluid collection: a comparison of different collection sites on the } \\
\text { external ventricular drain }\end{array}$ & $\begin{array}{l}2011 \\
\text { Canada }\end{array}$ & $\begin{array}{l}\text { Quasi-experimental } \\
\text { study por } \\
\text { convenience }\end{array}$ & Low \\
\hline $\begin{array}{l}\text { A multidisciplinary approach to end external ventricular drain infections in the } \\
\text { neurocritical care unit }\end{array}$ & $\begin{array}{l}2012 \\
\text { USA }\end{array}$ & Experience report & Low \\
\hline $\begin{array}{l}\text { Intraparenchymal vs Extracranial Ventricular Drain Intracranial Pressure Monitors in } \\
\text { Traumatic Brain Injury: Less Is More? }\end{array}$ & $\begin{array}{l}2012 \\
\text { USA }\end{array}$ & Cohort study & Moderate \\
\hline Factors contributing to ventriculostomy infection & $\begin{array}{l}2012 \\
\text { USA }\end{array}$ & Cohort study & Low \\
\hline $\begin{array}{l}\text { External ventricular drain infections: Successful implementation of strategies to } \\
\text { reduce infection rate }\end{array}$ & $\begin{array}{l}2012 \\
\text { Singapore }\end{array}$ & Cross-sectional study & Low \\
\hline $\begin{array}{l}\text { Impact of an educational intervention implanted in a neurological intensive care unit } \\
\text { on rates of infection related to external ventricular drains }\end{array}$ & $\begin{array}{l}2013 \\
\text { Brazil }\end{array}$ & $\begin{array}{l}\text { Quasi-experimental } \\
\text { study }\end{array}$ & Low \\
\hline A simple protocol to prevent external ventricular drain infections & $\begin{array}{l}2013 \\
\text { USA }\end{array}$ & Cohort study & Low \\
\hline Ventriculitis of the Central Nervous System. Critical Care Nursing Clinics of North America & $\begin{array}{l}2013 \\
\text { USA }\end{array}$ & Technical note & Very low \\
\hline
\end{tabular}


Chart 1 (concluded)

\begin{tabular}{|c|c|c|c|}
\hline Title & $\begin{array}{l}\text { Year } \\
\text { Country }\end{array}$ & Outlining & GRADE \\
\hline $\begin{array}{l}\text { Decreasing ventricular infections through the use of a ventriculostomy placement } \\
\text { bundle: Experience at a single institution }\end{array}$ & $\begin{array}{l}2013 \\
\text { USA }\end{array}$ & Experience report & Very low \\
\hline Bundle of measures for external cerebral ventricu/lar drainage-associated ventriculitis & $\begin{array}{l}2014 \\
\text { Greece }\end{array}$ & Case study & Low \\
\hline $\begin{array}{l}\text { Neuro-Intensive Treatment Targeting Intracranial Hypertension Improves Outcome in } \\
\text { Severe Bacterial Meningitis: An Intervention-Control Study }\end{array}$ & $\begin{array}{c}2014 \\
\text { Sweden }\end{array}$ & Case-control study & Moderate \\
\hline Are chlorhexidine-containing dressings safe for use with ventricular drainages? & $\begin{array}{l}2014 \\
\text { Germany }\end{array}$ & $\begin{array}{l}\text { Quasi-experimental } \\
\text { study by convenience }\end{array}$ & Low \\
\hline Predictors of extraventricular drain-associated bacterial ventriculitis & $\begin{array}{l}2014 \\
\text { USA }\end{array}$ & $\begin{array}{l}\text { Qualitative systematic } \\
\text { review }\end{array}$ & Moderate \\
\hline $\begin{array}{l}\text { External Ventricular and Lumbar Drain Device Infections in ICU Patients: A Prospective } \\
\text { Multicenter Italian Study }\end{array}$ & $\begin{array}{l}2015 \\
\text { Italy }\end{array}$ & $\begin{array}{l}\text { Multicentric cohort } \\
\text { study }\end{array}$ & Moderate \\
\hline $\begin{array}{l}\text { Impact of antibiotic- and silver-impregnated external ventricular drains on the risk of } \\
\text { infections: A systematic review and meta-analysis }\end{array}$ & $\begin{array}{l}2015 \\
\text { China }\end{array}$ & Meta-analysis & High \\
\hline Management of Intracranial Pressure & $\begin{array}{l}2015 \\
\text { USA }\end{array}$ & $\begin{array}{l}\text { Narrative literature } \\
\text { review }\end{array}$ & Low \\
\hline $\begin{array}{l}\text { External Ventricular Drains versus Intraparenchymal Intracranial Pressure Monitors in } \\
\text { Traumatic Brain Injury: A Prospective Observational Study }\end{array}$ & $\begin{array}{l}2015 \\
\text { China }\end{array}$ & Cross-sectional study & Low \\
\hline External ventricular drains: Management and complications & $\begin{array}{l}2015 \\
\text { USA }\end{array}$ & $\begin{array}{l}\text { Narrative literature } \\
\text { review }\end{array}$ & Low \\
\hline $\begin{array}{l}\text { Early monitoring of ventriculostomy-related infections with procalcitonin in patients } \\
\text { with ventricular drains }\end{array}$ & $\begin{array}{l}2015 \\
\text { Egypt }\end{array}$ & Cohort study & Low \\
\hline Evaluation of indication and outcome of external ventricular drainage in a tertiary ICU & $\begin{array}{l}2015 \\
\text { USA }\end{array}$ & Cohort study & Moderate \\
\hline $\begin{array}{l}\text { Gestion paramédicale de la dérivation ventriculaire externe en réanimation } \\
\text { neurochirurgicale }\end{array}$ & $\begin{array}{l}2016 \\
\text { France }\end{array}$ & Technical note & Very low \\
\hline $\begin{array}{l}\text { Silver-impregnated external-ventricular-drain-related cerebrospinal fluid infections: a } \\
\text { meta-analysis }\end{array}$ & $\begin{array}{l}2016 \\
\text { United } \\
\text { kingdom }\end{array}$ & Meta-analysis & High \\
\hline $\begin{array}{l}\text { Current practice of external ventricular drainage: a survey among neurosurgical } \\
\text { departments in Germany }\end{array}$ & $\begin{array}{l}2016 \\
\text { Germany }\end{array}$ & $\begin{array}{l}\text { Quanti-qualitative } \\
\text { research }\end{array}$ & Low \\
\hline $\begin{array}{l}\text { Critérios para banho de leito em unidade de terapia intensiva adulto: construção de um } \\
\text { protocolo assistencial }\end{array}$ & $\begin{array}{l}2016 \\
\text { Brazil }\end{array}$ & $\begin{array}{l}\text { Qualitative systematic } \\
\text { review }\end{array}$ & Moderate \\
\hline $\begin{array}{l}\text { The Insertion and Management of External Ventricular Drains: An Evidence-Based } \\
\text { Consensus Statement }\end{array}$ & $\begin{array}{l}2016 \\
\text { USA }\end{array}$ & Systematic review & Moderate \\
\hline $\begin{array}{l}\text { Establishment of an External Ventricular Drain Best Practice Guideline: The Quest for a } \\
\text { Comprehensive, Universal Standard for External Ventricular Drain Care }\end{array}$ & $\begin{array}{l}2016 \\
\text { USA }\end{array}$ & $\begin{array}{l}\text { Qualitative systematic } \\
\text { review }\end{array}$ & Moderate \\
\hline $\begin{array}{l}\text { Riesgo de ventriculitis asociado a cuidados del drenaje ventricular externo en pacientes } \\
\text { neurocríticos }\end{array}$ & $\begin{array}{l}2016 \\
\text { Spain }\end{array}$ & Case-control study & Moderate \\
\hline $\begin{array}{l}\text { External Ventricular Catheters: Is It Appropriate to Use an Open/Monitor Position to } \\
\text { Adequately Trend Intracranial Pressure in a Neuroscience Critical Care Environment? }\end{array}$ & $\begin{array}{l}2016 \\
\text { USA }\end{array}$ & Cohort study & Moderate \\
\hline $\begin{array}{l}\text { Risks of Routinely Clamping External Ventricular Drains for Intrahospital Transport in } \\
\text { Neurocritically III Cerebrovascular Patients }\end{array}$ & $\begin{array}{l}2017 \\
\text { USA }\end{array}$ & Cohort study & Low \\
\hline $\begin{array}{l}\text { The effects of ventricular drainage on the intracranial pressure signal and the } \\
\text { pressure reactivity index }\end{array}$ & $\begin{array}{c}2017 \\
\text { Sweden }\end{array}$ & Cohort study & Very low \\
\hline $\begin{array}{l}\text { Physiological Effects of Early Incremental Mobilization of a Patient with Acute } \\
\text { Intracerebral and Intraventricular Hemorrhage Requiring Dual External Ventricular } \\
\text { Drainage }\end{array}$ & $\begin{array}{l}2017 \\
\text { USA }\end{array}$ & Case study & Very low \\
\hline $\begin{array}{l}\text { Implementation of an Early Mobility Pathway in Neurointensive Care Unit Patients } \\
\text { With External Ventricular Devices }\end{array}$ & $\begin{array}{l}2017 \\
\text { USA }\end{array}$ & Case-control study & Moderate \\
\hline Intracranial Pressure Values Are Highly Variable After Cerebral Spinal Fluid Drainage & $\begin{array}{l}2017 \\
\text { USA }\end{array}$ & Case study & Low \\
\hline Caring for neurosurgical patients with external ventricular drains & $\begin{array}{l}2018 \\
\text { United kingdom }\end{array}$ & $\begin{array}{l}\text { Narrative literature } \\
\text { review }\end{array}$ & Low \\
\hline $\begin{array}{l}\text { Early Ambulation in Patients With External Ventricular Drains: Results of a Quality } \\
\text { Improvement Project }\end{array}$ & $\begin{array}{l}2018 \\
\text { USA }\end{array}$ & Cohort study & Low \\
\hline
\end{tabular}

Note: ICU - Intensive Care Unit 
Articles with less evidence were not excluded due to the scarcity of studies with a strong degree of recommendation in the thematic area. Figure 2 shows the mapping of the 54 studies selected according to their respective themes. It is noteworthy that the intersections of this set are referred to studies that cover the two central themes (Figure 2).

From the selected studies, there were twenty nursing care, divided into nine categories, namely: patient positioning; EVD drainage system positioning; dressing change; EVD drainage bag and catheter care; CSF care; CSF measurement; administration of medication in the catheter; CSF collection; and mobilization of patients with EVD (Chart 2).

It is noteworthy that assessment of the quality of the evidence of each listed care was staggered according to the low quality among those used. For instance, in a care that has as reference studies of moderate quality and low quality, in the concept of the final assessment, it will be classified as low quality, according to what is recommended in the guideline on the use of GRADE ${ }^{(17)}$.

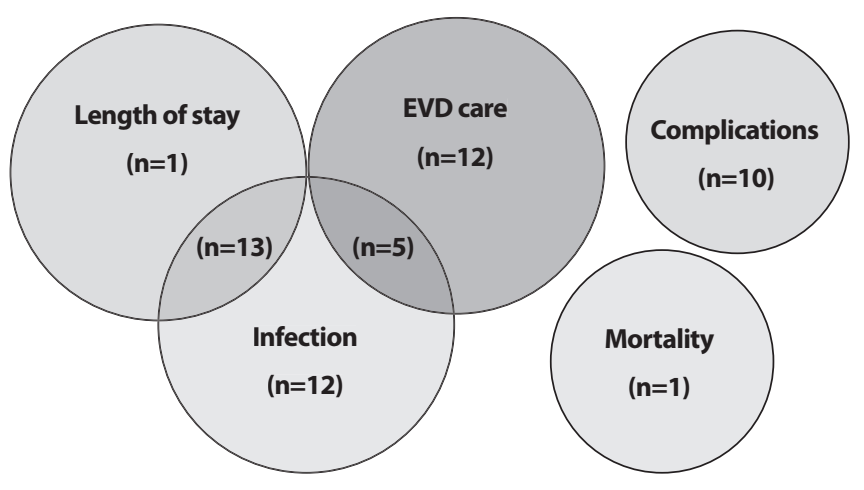

Note: EVD - external ventricular drain.

Figure 2 - Mapping of the selected studies $(n=54)$ in the scoping review regarding the approach to external ventricular drain

Chart 2 - Main nursing care for adult patients undergoing external ventricular drain according to the literature review and degree of evidence assessed by Grading of Recommendations, Assessment, Development and Evaluation

\begin{tabular}{|c|c|c|c|}
\hline Category & Intervention & Justification & $\begin{array}{l}\text { Degree of } \\
\text { evidence }\end{array}$ \\
\hline \multirow{3}{*}{ 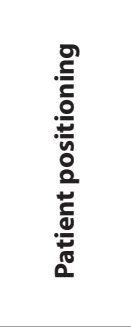 } & $\begin{array}{l}\text { Headboard angle } \\
\text { between } 15 \text { and } 30^{\circ}\end{array}$ & $\begin{array}{l}\text { Leveling the headland angle between } 15 \text { and } 30^{\circ} \text { in line with the system level ensures proper } \\
\text { functioning and reliability of monitoring }{ }^{(18-19)} \text {; }\end{array}$ & Moderate \\
\hline & $\begin{array}{l}\text { Keeping head in } \\
\text { neutral position } \\
\text { aligned to cervical }\end{array}$ & $\begin{array}{l}\text { The aim is to facilitate venous return, reducing CSF without interfering with the EVD drainage } \\
\text { system }^{(18-19)} \text {; }\end{array}$ & Moderate \\
\hline & $\begin{array}{l}\text { Repositioning at } \\
\text { "zero point" }\end{array}$ & $\begin{array}{l}\text { The system review must be carried out in order to avoid any change in the drain back } \\
\text { pressure } \mathrm{e}^{(5)} \text {. For example, if the transducer is above the interventricular foramen, a false CSF } \\
\text { will be recorded as well as insufficient drainage of CSF, with an unnoticed ICH that may cause } \\
\text { ventricular collapse or subdural collection }{ }^{(19)} \text {. }\end{array}$ & Low \\
\hline \multirow{2}{*}{ 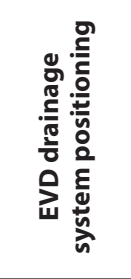 } & Flow level height & $\begin{array}{l}\text { The height of the flow level of CSF by convention corresponds to a horizontal line that runs from the } \\
\text { interventricular foramen to the counter pressure prescribed by the neurosurgeon, usually between } \\
10 \text { and } 20 \mathrm{cmH}_{2} \mathrm{O}^{(5,19-2)} \text {. This means that if it is } 10 \mathrm{cmH}_{2} \mathrm{O}, \mathrm{EVD} \text { is } 10 \mathrm{~cm} \text { from foramen and, to drain } \\
\text { CSF, pressure of ventricles must be at least } 10 \mathrm{cmH}_{2} \mathrm{O} \text {; }\end{array}$ & Low \\
\hline & System clamping & $\begin{array}{l}\text { The clamped system must be kept as short as possible. However, clamping of up to } 30 \text { minutes } \\
\text { is considered safe, considered a sufficient period to perform intra-hospital transports, exams } \\
\text { and changes in patient positioning }{ }^{(5)} \text {, unclamping and verifying the complete system in } \\
\text { sequence }^{(19,21)} \text {; }\end{array}$ & Low \\
\hline \multirow{3}{*}{ 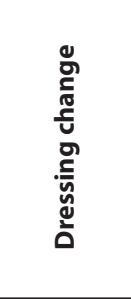 } & $\begin{array}{l}\text { Frequency of } \\
\text { dressing assessment }\end{array}$ & $\begin{array}{l}\text { To verify the appearance of the dressing every } 6 \text { hours, if there is moisture indicative of leakage } \\
\text { of CSF or signs of inflammation when inserting the catheter }{ }^{(20)} \text {; }\end{array}$ & Low \\
\hline & $\begin{array}{l}\text { Use of gauze } \\
\text { dressing }\end{array}$ & $\begin{array}{l}\text { Dressing should be performed with } 0.9 \% \text { saline and alcoholic chlorhexidine every } 24 \text { hours or } \\
\text { earlier if necessary, paying attention to and recording the appearance of the insertion, covering } \\
\text { with sterile gauze and bandage }{ }^{(22)} \text {; }\end{array}$ & Moderate \\
\hline & $\begin{array}{l}\text { Use of transparent } \\
\text { film dressing }\end{array}$ & $\begin{array}{l}\text { When transparent film is impermeable, dressing should be applied weekly or earlier if necessary } \\
\text { either by compromising the integrity of the dressing or detachment, in order to minimize direct } \\
\text { contact between catheter and external environment }{ }^{(20,22-23)} \text {. }\end{array}$ & Low \\
\hline \multirow{4}{*}{ 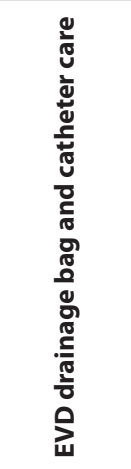 } & $\begin{array}{l}\text { Aseptic technique } \\
\text { for handling }\end{array}$ & $\begin{array}{l}\text { Handling must be kept to a minimum in order to ensure that the risk of infection is minimized } \\
\text { and the touch of the EVD components, whether in the cannula or in the bag, are considered } \\
\text { aseptic procedures }{ }^{(24)} \text {; }\end{array}$ & Low \\
\hline & $\begin{array}{l}\text { Limit capacity to } \\
\text { despise the contents } \\
\text { of the bag }\end{array}$ & $\begin{array}{l}\text { The drainage bag must be emptied when it reaches } 2 / 3 \text { or } 3 / 4 \text { of its volume capacity. When } \\
\text { very full, it can become heavy and may alter or even interrupt the operation of the CSF drainage } \\
\text { system }{ }^{(24)} \text {. This same care must be applied to the drip burette; }\end{array}$ & Low \\
\hline & $\begin{array}{l}\text { Watching for signs of } \\
\text { catheter obstruction }\end{array}$ & $\begin{array}{l}\text { It is important to note that the flow of the dropper from the system is well positioned. If } \\
\text { there is minimal or no drainage, the system must be checked for folds, obstructions or any } \\
\text { clamping. Drainage reduction can cause hydrocephalus remodeling or indicate other possible } \\
\text { complications, including catheter traction or CSF leak }{ }^{(19)} \text {. }\end{array}$ & Moderate \\
\hline & $\begin{array}{l}\text { In cases of catheter } \\
\text { traction }\end{array}$ & $\begin{array}{l}\text { Do not try to reposition it, or even aspirate or administer solutions when it is obstructed, but } \\
\text { communicate with the neurosurgery staff whenever there are any changes, due to high risk of } \\
\text { infection and complications }{ }^{(19)} \text {. }\end{array}$ & Moderate \\
\hline
\end{tabular}




\begin{tabular}{|c|c|c|c|}
\hline Category & Intervention & Justification & $\begin{array}{l}\text { Degree of } \\
\text { evidence }\end{array}$ \\
\hline \multirow{3}{*}{ 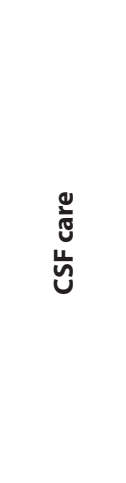 } & $\begin{array}{l}\text { Monitoring the level } \\
\text { of consciousness }\end{array}$ & $\begin{array}{l}\text { Careful assessments of the level of consciousness should be performed using the updated Glasgow } \\
\text { Coma Scale, especially in cases of confused or cognitively impaired patients, in order to ensure that } \\
\text { catheter remains properly fixed and is not accidentally pulled in cases of psychomotor agitation. } \\
\text { Moreover, early neurological deterioration and signs of lowering of the sensorium due to excessive } \\
\text { CSF drainage should be monitored and detected (22); }\end{array}$ & Low \\
\hline & CSF drainage flow & $\begin{array}{l}\text { Drainage flow varies according to the height of the collecting system in relation to "zero point" } \\
\text { (usually } 20 \mathrm{cmH}_{2} \mathrm{O} \text { ) and usually stays between } 5 \text { and } 10 \mathrm{ml} / \mathrm{h} \text { or, in some cases, up to } 15 \mathrm{ml} / \mathrm{h} \text {. The } \\
\text { volume of } \mathrm{CSF} \text { drained in } \mathrm{ml} \text { should be recorded every 6-hour shift, calculating the total of } 24 \text { hours. } \\
\text { Excess drainage can cause ventricular collapse, rupture of vessels and even subdural hematoma }{ }^{(19)} \text {; }\end{array}$ & Moderate \\
\hline & $\begin{array}{l}\text { Characteristics of } \\
\text { drained CSF }\end{array}$ & $\begin{array}{l}\text { The nursing staff must be aware of any changes in the color of the drained CSF, which can } \\
\text { change according to patients' clinical pathologies. For instance, if there is blood in CSF, it can } \\
\text { be indicative of cerebral hemorrhage or if it looks cloudy or with sediment it can indicate } \\
\text { an infectious process. Therefore, it is important to communicate with the nurse and the } \\
\text { neurosurgery staff whenever an atypical CSF stain is identified }{ }^{(19)} \text {. }\end{array}$ & Moderate \\
\hline 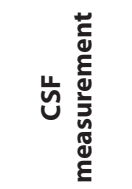 & $\begin{array}{l}\text { Clamping the system } \\
\text { to measure CSF }\end{array}$ & $\begin{array}{l}\text { When the EVD system is open, the transducer may not represent the CSF wave correctly. } \\
\text { Therefore, the system must be clamped for } 1 \text { minute so that the wave analysis is more accurate, } \\
\text { taking care to unclamp the system immediately afterwards }{ }^{(19)} \text {. }\end{array}$ & Moderate \\
\hline 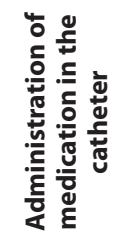 & $\begin{array}{l}\text { Clamping the system } \\
\text { after administration }\end{array}$ & $\begin{array}{l}\text { When drugs are introduced by the neurosurgery staff through the EVD catheter, such as tissue } \\
\text { plasminogen activator for cases of intraventricular hemorrhage or antibiotics for ventriculitis, } \\
\text { the system should be clamped for about } 1 \text { hour after administration so that it is not drained } \\
\text { with excess } \text { CSF }^{(5)} \text {. }\end{array}$ & Low \\
\hline \multirow[b]{2}{*}{ 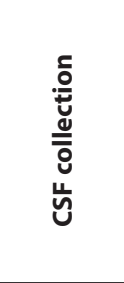 } & $\begin{array}{l}\text { CSF collection } \\
\text { periodicity }\end{array}$ & $\begin{array}{l}\text { It should be performed only when necessary, especially in cases in which infection is suspected, } \\
\text { which is why routine collection is not indicated }\end{array}$ & Moderate \\
\hline & CSF collection site & $\begin{array}{l}\text { It is recommended that the sample be collected at the distal port, as it minimizes the risk } \\
\text { of infection of the system and can bring a more accurate diagnosis, in addition to being } \\
\text { considered safe and easy for collection }{ }^{(22)} \text {. However, when the sample is collected in this way, all } \\
\text { CSF volume present in the drip chamber/burette must be collected and tested for an accurate } \\
\text { leukocyte count. Collection in the bag should be avoided due to the rapid degradation of CSF } \\
\text { components. It is also noteworthy that this procedure is performed by the neurosurgery staff }{ }^{(5)} \text {. }\end{array}$ & Low \\
\hline 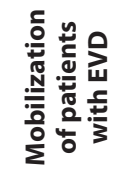 & Early mobilization & $\begin{array}{l}\text { Early mobilization is considered a viable and safe alternative when patients are stable. Such } \\
\text { mobilization does not alter CSF and PPC parameters in patients with EVD } \\
\text { favorable clinical conditions (MAP }>80 \mathrm{mmHg} \text { and } \text { CSF }<20 \mathrm{mmHg} \text { ), it can be safely tolerated } \\
\text { and minimal risks to patients, which may decrease the time of hospitalization and adverse } \\
\text { events }{ }^{(26)} \text {. }\end{array}$ & Low \\
\hline
\end{tabular}

Note: CSF - intracranial pressure; EVD - external ventricular drain; ICH - intracranial hypertension; CPP - cerebral perfusion pressure; $M A P$ - mean arterial pressure.

\section{DISCUSSION}

From the studies selected in this review, 20 nursing care for patients undergoing EVD stood out, which were subdivided into subcategories highlighting the importance of nursing care in each procedure. The evidence on which these findings are based varies from moderate to very low, an assessment already expected considering the characteristics of patients and type of procedure. Although the findings come from observational studies, they are the best possible evidence available to assess care practice and, therefore, such findings can contribute to care qualification.

Considering the weaknesses and specificities of caring for patients with brain injury and the need to qualify care based on evidence-based practice, it is highlighted that the role of nursing is fundamental and has been gaining more visibility. Nurses are responsible for caring for patients with EVD and, in large part, for catheter and system care. Nursing must ensure proper placement, placement, sterility and integrity of the EVD collection system ${ }^{(5)}$. Assessment, prevention, control and identification of risk situations that may occur with the EVD system are also considered, avoiding possible complications and qualifying assistance ${ }^{(27)}$.

For positive results in relation to critical nursing care associated with EVD, comprehensive neurological assessments, care related to the proper maintenance of the drainage system, among others stand out ${ }^{(28)}$. Nurses are responsible for monitoring CSF, as well as for frequent neurological assessment, in line with the medical assessment. The nursing staff must monitor signs indicating infection, bleeding, document aspects of the drainage system, in addition to providing emotional support to patients' family ${ }^{(29)}$. Moreover, sometimes nurses perform CSF drainage as directed, to decrease CSF when elevated ${ }^{(30)}$.

Nurses are also responsible for promoting best EVD care practices, monitoring and managing the system and draining. Careful assessments of the level of consciousness should be performed, especially in cases of confused or cognitively impaired patients, 
in order to ensure that the catheter remains properly fixed and is not pulled or accidentally removed due to some period of psychomotor agitation ${ }^{(31)}$.

Managing CSF by EVD is essential for the treatment and prevention of complications such as cerebral hypoperfusion, hemorrhages and even brain death. Early recognition of signs and symptoms of elevation is essential to promote safe care, highlighting: headache, papilledema, nausea and vomiting and, in more severe cases, stupor, coma, pupillary changes, limb paresis to respiratory changes ${ }^{(32)}$. Medical options for treating elevated CSF include elevation of the head of the bed, intravenous mannitol, hypertonic saline, transient hyperventilation, barbiturates and, if CSF remains refractory, sedation, endotracheal intubation, mechanical ventilation and neuromuscular block ${ }^{(32)}$. Furthermore, attention should be paid to warning signs of infection, their identification and elimination of preventable risk factors ${ }^{(20,31)}$.

Therefore, attention must be paid to all signs presented by patients, registering and communicating them. Sensory and alteration of consciousness should be observed, checking for any focal neurological deficit, seizures without an apparent cause, neck stiffness or hyperthermia with no apparent focus; drainage control preferably every six hours or earlier, if necessary; liquid drained volume record, observing its color and appearance in order to watch for signs of opacity considered indicators of infection ${ }^{(6,33)}$.

It was identified that the ideal positioning of the head of patients with EVD is at an angle between 15 and $30^{\circ}$, in a neutral position, keeping the drainage system positioned from the "zero point". This point allows the pressure transducer to be in line with the interventricular foramen. This means that the best practice for the positioning of the drainage system corresponds to the level of the external auditory canal of the ear, corresponding to the line between the eyebrows seen from the side angle. It is adjusted to the height specified by neurosurgeons according to the clinical conditions of each patient so that CSF is more reliable ${ }^{(19,34)}$.

It is recommended to manipulate the EVD system as little as possible in order to prevent an increase in infections related to catheter and system manipulation. Therefore, it is essential that professionals perform care in aseptic conditions, through hand hygiene and antisepsis, with water, soap, alcohol gel and also the use of sterile gloves when handling the system to empty the bag ${ }^{(1,24)}$.

As for the collection bag, it must be avoided that the drainage volume is greater than $2 / 3$ or $3 / 4$ of its capacity and also that the drained content does not remain more than 24 hours in the reservoir, needing to be emptied before this period. It is important to use the sterile technique for its performance and to observe the characteristics of the drained CSF, positioning of the system and the catheter, checking if it is functioning properly, without signs of obstruction ${ }^{(19,24)}$.

To assist the tissue healing process of the place where EVD catheter was inserted, it is recommended that the dressing be performed with a sterile technique, as well as any procedure in the system, in order to avoid local and systemic infection. Its frequency may vary according to the dressing applied, that is, daily if the dressing is gauze or weekly if the dressing is film ${ }^{(20,22-23)}$. Regardless of the type of dressing, whose availability of material inputs is a relevant factor, there is a need to use aseptic technique, paying attention to any signs of complications with the catheter ${ }^{(19)}$.
To measure CSF through EVD, when the system made available by the health institution does not allow measurement of CSF on the monitor constantly, it is recommended that the system be clamped prior to measurement and the outlet is closed for EVD and kept open for CSF, so that the measured pressure is reliable, through waves in the transducer. It is believed that if EVD is kept open during measurement, wave reading can have significant effects on $\operatorname{CSF}^{(19,35)}$.

In situations where it is necessary to mobilize patients, whether for transport or changes in decubitus, it is necessary to close the EVD system before this process. And, after the end of mobilization, performance of measurement again for height adjustments of the system ${ }^{(5,19,21)}$. Failure to perform this measure may result in complications for patients, for instance, risk of ventricular collapse, reflux towards the ventricular system and also the risk of infection of the central nervous system ${ }^{(1,6)}$.

The maximum EVD system length was not identified, since there is no consensus between the studies. It was observed that each study reported the average catheter stay in the patients in question, but did not stipulate a time limit for patients to maintain the system. It was evidenced that EVD length among the studies assessed ranged from 1.5 to 44 days. However, despite not being linear, there is a relationship between EVD length and risk of infection. Risk factors for infection are associated with the length of stay, frequency of unnecessary CSF collection, ventricular hemorrhages and the surgical technique used ${ }^{(35-37)}$. It is also recommended that the EVD catheter be removed or replaced as soon as possible, depending on the need to use the system to avoid more serious complications and infections ${ }^{(38)}$.

Concerning using prophylactic alternatives in an attempt to contribute to infection prevention, some studies have assessed infection rates by comparing different types of catheters (simple, impregnated with antibiotics and impregnated with silver). It was found that the use of impregnated catheters, either with antibiotics or silver, contributes to the reduction of infection rates when compared to the traditional catheter ${ }^{(22,39)}$. However, the data found so far are insufficient to verify the preference for silver or antibiotics. It was observed that both were able to reduce the infection rate ${ }^{(40)}$, finding that these new alternatives are safer and decrease the risk of infection related to the EVD catheter ${ }^{(41-43)}$, but that there is still a need more studies in the area.

A study carried out in the USA in 2016 highlights ten protocols in different countries regarding EVD care, revealing that the measures were effective in reducing infection rates in the system ${ }^{(22)}$. The study depicts the comparison of infection rate percentage before and after interventions proposed in each study. Among the ten protocols assessed, six obtained a percentage equal to or greater than $75 \%$ in relation to the decrease in infection rates related to the EVD system after introduction of measures in their respective institutions. This data confirms that dedication of staff to perform care correctly and cautiously is able to reduce and prevent infections related to the EVD system. Furthermore, it contributes to better recovery and decreased hospitalization time for these patients.

It is believed that the qualified search for the best available evidence can contribute to better health outcomes. However, both the theme of evidence-based practice and systematic scoping review are still under-explored within the scope of publication in recent years. 


\section{Study limitation}

This study presented as a limitation the inclusion of studies only in English, Portuguese and Spanish, in addition to some studies excluded because they are not available in full. These factors may not have increased the number of studies eligible for this research.

\section{Contributions to nursing}

Concerning implications for nursing, it is necessary to include in the daily care praxis best-evidence based care available to date. It is important to develop nursing care protocols that can support care, ensuring that care is effective, qualified, and safe. We must inspire and encourage studies on professional practices so that the actions performed can be based on scientific evidence.

\section{CONCLUSIONS}

In relation to nursing staff care for adult patients undergoing EVD, there is an adequate positioning and mobilization of patients in bed, management of the EVD drainage system and catheter, CSF monitoring, CSF collection and medication administration. The last two procedures are performed by the neurosurgeon and care is related under the responsibility of nursing. These findings corroborate the nursing care qualification. The best practices for safe and standardized care that aim to prevent outcomes such as system length of stay, complications, infection or death related to EVD stand out.

\section{REFERENCES}

1. Grille P, Costa G, Biestro A, Wajskopf S. Manejo del drenaje ventricular externo en la unidad de cuidados intensivos. Guía práctica. Rev Méd Urug [Internet]. 2007 [cited 2019 Oct 30];23(1):50-5. Available from: http://www.scielo.edu.uy/pdf/rmu/v23n1/v23n1a07.pdf

2. Estévez Atienza M, Castany JR. [External ventricular drainage: nursing Care]. Rev Enferm. 2003;26(4):9-12 Spanish. https://doi. org/10.1097/01376517-199112000-00002

3. Brain Trauma Foundation. Guidelines for the Management of Severe Traumatic Brain Injury. 4th ed [Internet]. 2016 [cited 2018 May 20]. Available from: https://braintrauma.org/uploads/03/12/Guidelines_for_Management_of_Severe_TBI_4th_Edition.pdf

4. Scholz C, Hubbe U, Deininger M, Deininger MH. Hemorrhage rates of external ventricular drain (EVD), intracranial pressure gauge (ICP) or combined EVD and ICP gauge placement within $48 \mathrm{~h}$ of endovascular coil embolization of cerebral aneurysms. Clin Neurol Neurosurg. 2013;115(8):1399-402. https://doi.org/10.1016/j.clineuro.2013.01.023

5. Muralidharan R. External ventricular drains: management and complications. Surg Neurol Int. 2015;6(6):271-4. https://doi. org/10.4103/2152-7806.157620

6. American Association of Neuroscience Nurses. Care of the patient undergoing intracranial pressure monitoring: external ventricular drainage or lumbar drainage. AANN Clinical Practice Guideline Series [Internet]. 2011 [cited 2018 May 20]. Available from: http://files. mmintensivecare.webnode.pt/200000471-ad055ad4d0/Intracranial\%20Pressure\%20Monitoring.pdf

7. McNett $\mathrm{M}$, Olson DM. Evidence to guide nursing interventions for critically ill neurologically impaired patients with ICP monitoring. $J$ Neurosci Nurs. 2013;45(3):120-3. https://doi.org/10.1097/JNN.0b013e3182901f0a

8. Taylor CR, Lillis C, LeMone P, Lynn P. Fundamentos de enfermagem: a arte e a ciência do cuidado de enfermagem. 7. ed. Porto Alegre: Artmed, 2014. 1768 p.

9. Bandeira AG, Witt RR, Lapão LV, Madruga JG. A utilização de um referencial metodológico na implementação de evidências como parte da investigação em enfermagem. Texto Contexto Enferm. 2017;26(4):e2550017. https://doi.org/10.1590/0104- 07072017002550017

10. Weng YH, Chen C, Kuo KN, Yang CY, Lo HL, Chen KH. Implementation of evidence-based practice in relation to a clinical nursing ladder system: a national survey in Taiwan. Worldviews Evid Based Nurs. 2015;12(1):22-30. https://doi.org/10.1111/wvn.12076

11. Aromataris E, Munn Z (Eds). Joanna Briggs Institute Reviewer's Manual. The Joanna Briggs Institute [Internet]. 2017 [cited 2018 May 20]. Available from https://reviewersmanual.joannabriggs.org/

12. Arksey H, O'Malley L. Scoping studies: Towards a Methodological Framework. Int J Soc Res Methodol. 2005;8:19-32. https://doi. org/10.1080/1364557032000119616

13. Levac D, Colquhoun H, O’Brien KK. Scoping studies: advancing the methodology. Implementation Sci. 2010;5:1-9. doi:10.1186/1748-5908-5-69

14. Peterson J, Pearce PF, Ferguson LA, Langford CA. Understanding scoping reviews: definition, purpose, and process. J Am Assoc Nurse Pract. 2017;29(1):12-16. https://doi.org/10.1002/2327-6924.12380

15. Peters M, Godfrey CM, Khalil H, McInerney P, Parker D, Soares CB. Guidance for conducting systematic scoping reviews. Int J Evidence-Based Healthcare. 2015;13(3):141-6. https://doi.org/10.1097/XEB.0000000000000050

16. Tricco AC, Lillie E, Zarin W, O'Brien KK, Colquhoun H, Levac D, et al. PRISMA Extension for Scoping Reviews (PRISMA-ScR): checklist and explanation. Ann Intern Med [Internet]. 2018 [cited 2018 May 20]. Avaliable from: http://www.equator-network.org/reporting-guidelines/prisma-scr/

17. Ministério da Saúde (BR). Secretaria de Ciência, Tecnologia e Insumos Estratégicos. Departamento de Ciência e Tecnologia. Diretrizes Metodológicas: Sistema GRADE - Manual de graduação da qualidade da evidência e força de recomendação para tomada de decisão em saúde. Brasília: Ministério da Saúde, 2014. 
18. Flores GP. Critérios para banho de leito em unidade de terapia intensiva adulto: construção de um protocolo assistencial. [Dissertação] [Internet]. Universidade do Vale do Rio dos Sinos. 2016 [cited 2018 May 20]. Available from: http://www.repositorio.jesuita.org.br/handle/ UNISINOS/5279

19. Woodward S, Addison C, Shah S, Brennan F, MacLeod A, Clements M. Benchmarking best practice for external ventricular drainage. Br J Nurs. 2002;11(1):47-53. https://doi.org/10.12968/bjon.2002.11.1.12217

20. Hill M, Baker G, Carter D, Henman LJ, Marshall K, Mohn K, et al. A multidisciplinary approach to end external ventricular drain infections in the neurocritical care unit. J Neurosci Nurs. 2012;44(4):188-93. https://doi.org/10.1097/JNN.0b013e3182527672

21. Chaikittisilpa N, Lele AV, Lyons VH, Nair BG, Newman SF, Blissitt PA, et al. Risks of routinely clamping external ventricular drains for intrahospital transport in neurocritically ill cerebrovascular patients. Neurocrit Care. 2017;26(2):196-204. https://doi.org/10.1007/ s12028-016-0308-0

22. Hepburn-Smith M, Dynkevich I, Spektor M, Lord A, Czeisler B, Lewis A. Establishment of an external ventricular drain best practice guideline: the quest for a comprehensive, universal standard for external ventricular drain care. J Neurosci Nurs. 2016;48(1):54-65. https://doi. org/10.1097/JNN.000000000000017

23. Flint AC, Rao VA, Renda NC, Faigeles BS, Lasman TE, Sheridan W. A simple protocol to prevent external ventricular drain infections. Neurosurgery. 2013;72(6):993-9. https://doi.org/10.1227/NEU.0b013e31828e8dfd

24. Humphrey E. Caring for neurosurgical patients with external ventricular drains. Nurs Times [Internet]. 2018 [cited 2018 May 20];114(4):52-6. Available from: https://www.nursingtimes.net/clinical-archive/neurology/caring-for-neurosurgical-patients-with-external-ventriculardrains/7023833.article

25. Kumble S, Zink EK, Burch M, Deluzio S, Stevens RD, Bahouth MN. Physiological effects of early incremental mobilization of a patient with acute intracerebral and intraventricular hemorrhage requiring dual external ventricular drainage. Neurocrit Care. 2017;27(1):115-9. https:// doi.org/10.1007/s12028-017-0376-9

26. Shah SO, Kraft J, Ankam N, Bu P, Stout K, Melnyk S, et al. Early ambulation in patients with external ventricular drains: results of a quality improvement project. J Intensive Care Med. 2018;33(6):370-4. https://doi.org/10.1177/0885066616677507

27. Díaz CL. Paciente neurocrítico. cuidados de enfermería. Rev Enferm [Internet]. 2009 [cited 2018 May 20];32(12):841-50. Available from: http://pesquisa.bvsalud.org/brasil/resource/pt/ibc-76283

28. Cummings, R. Understanding external ventricular drainage. J Neurosci Nurs [Internet]. 1992 [cited 2018 May 20];24(2):84-7. Available from: https://www.ncbi.nlm.nih.gov/pubmed/1602175

29. Pope W. External ventriculostomy: a practical application for the acute care nurse. J Neurosci Nurs [Internet]. 1998 [cited 2018 May 20];30(3):185-90. Available from: https://www.ncbi.nlm.nih.gov/pubmed/9689610

30. Sunderland NE, Villanueva NE, Pazuchanics SJ. External ventricular catheters: is it appropriate to use an open/monitor position to adequately trend intracranial pressure in a neuroscience critical care environment? J Neurosci Nurs. 2016;48(5):274-7. https://doi. org/10.1097/JNN.0000000000000255

31. Guanci MM. Ventriculitis of the central nervous system. Crit Care Nurs Clin North Am. 2013;25(3):399-406. https://doi.org/10.1016/j.ccell.2013.04.005

32. Freeman WD. Management of intracranial pressure. Continuum (Minneap Minn). 2015;21(5):1299-323. https://doi.org/10.1212/ CON.0000000000000235

33. Rosa NM, Lima JF, Inoue KC. Conhecimento da equipe de enfermagem sobre neurointensivismo e a influência da educação continua. Cienc Cuid Saude. 2013;12(1):112-20. https://doi.org/10.4025/cienccuidsaude.v12i1.15031

34. Mostofi K, Khouzani RK. Surface anatomy for implantation of external ventricular drainage: some surgical remarks. Surg Neurol Int. 2016;7(22):577-80. https://doi.org/10.4103/2152-7806.189437

35. Liu H, Wang W, Cheng F, Yuan Q, Yang J, Hu J, et al. External ventricular drains versus intraparenchymal intracranial pressure monitors in traumatic brain injury: a prospective observational study. World Neurosurg. 2015;83(5):794-800. https://doi.org/10.1016/j.wneu.2014.12.040

36. Williamson R, Phillips-Bute B, McDonagh D, Gray M, Zomorodi A, Olson DM, et al. Predictors of extraventricular drain-associated bacterial ventriculitis. J Crit Care. 2014;29(1):77-82. https://doi.org/10.1016/j.jcrc.2013.08.012

37. Beer R, Lackner P, Pfausler B, Schmutzhard E. Nosocomial ventriculitis and meningitis in neurocritical care patients. J Neurol. 2008;255(11):1617-24. https://doi.org/10.1007/s00415-008-0059-8

38. Sinha S, Chaudhuri S. Evaluation of indication and outcome of external ventricular drainage in a tertiary ICU. Crit Care Med. 2015;43(12):136. https://doi.org/10.1097/01.ccm.0000474367.26395.78

39. Rivero-Garvía M, Márquez-Rivas J, Jiménez-Mejías ME, Neth O, Rueda-Torres AB. Reduction in external ventricular drain infection rate: impact of a minimal handling protocol and antibiotic-impregnated catheters. Acta Neurochir (Wien). 2011;153(3):647-51. https://doi. org/10.1007/s00701-010-0905-1

40. Cui Z, Wang B, Zhong Z, Sun Y, Sun Q, Yang G, et al. Impact of antibiotic- and silver-impregnated external ventricular drains on the risk of infections: a systematic review and meta-analysis. Am J Infect Control. 2015;43(7):23-32. https://doi.org/10.1016/j.ajic.2015.03.015

41. Atkinson R, Fikrey L, Vail A, Patel H. Silver-impregnated external-ventricular-drain-related cerebrospinal fluid infections: a meta-analysis. J Hosp Infect. 2016;92(3):263-72. https://doi.org/10.1016/j.jhin.2015.09.014 
42. Cinibulak Z, Aschoff A, Apedjinou A, Kaminsky J, Trost HA, Krauss JK. Current practice of external ventricular drainage: a survey among neurosurgical departments in Germany. Acta Neurochir (Wien). 2016;158(5):847-53. https://doi.org/10.1007/s00701-016-2747-y

43. Citerio G, Signorini L, Bronco A, Vargiolu A, Rota M, Latronico N. External ventricular and lumbar drain device infections in ICU patients: a prospective multicenter Italian Study. Crit Care Med. 2015;43(8):1630-7. https://doi.org/10.1097/CCM.0000000000001019 